$$
\begin{gathered}
\text { The } \\
\text { Harvest } \\
\frac{\text { OF THE }}{\text { Hills }}
\end{gathered}
$$





\section{The \\ Harvest \\ OF THE \\ Hills}

Rural Life in Northern England and the Scottish Borders, 1400-1700

ANGUS J. L. WINCHESTER

$\frac{\text { EDINBURGH }}{\text { University Press }}$ 
(C) Angus J. L. Winchester, 2000

Edinburgh University Press Ltd

22 George Square, Edinburgh

Reprinted 2002

Transferred to digital printing 2006

Typeset in Palatino Light

by Pioneer Associates, Perthshire.

Printed and bound in Great Britain by CPI Antony Rowe, Eastbourne

A CIP record for this book is available from the British Library

ISBN-10 1853312398 (paperback)

ISBN-13 9781853312397

The right of Angus J. L. Winchester to be identified as author of this work has been asserted in accordance with the Copyright, Designs and Patents Act 1988. 
To my parents,

who gave me a love of the hills. 
